\title{
Evaluation of thyroid function and autoimmunity in HIV-infected women
}

\author{
Avaliação da função tiroidiana e autoimunidade \\ em mulheres infectadas pelo HIV
}

Leiliane Gonçalves de Carvalho', Patrícia de Fátima dos Santos Teixeira ${ }^{1,2}$, Ana Luiza Brandão Galotti Panico', Marcela Vaisberg Cohen', Maria Fernanda Miguens Castelar Pinheiro ${ }^{3}$, Paulo Feijó Barroso ${ }^{1,4}$, Mário Vaisman ${ }^{1,2}$

1 Faculdade de Medicina, Universidade Federal do Rio de Janeiro (UFRJ), Rio de Janeiro, RJ, Brazil

${ }^{2}$ Hospital Universitário Clementino Fraga Filho (HUCFF),

UFRJ, Endocrinologia, Rio de Janeiro, RJ, Brazil

${ }^{3}$ Sérgio Franco Medicina Diagnóstica, Rio de Janeiro, RJ, Brazil ${ }^{4}$ HUCFF/UFRJ, Doenças Infecto-Parasitárias (DIP) Rio de Janeiro, RJ, Brazil

Correspondence to:

Leiliane Gonçalves de Carvalho Hospital Universitário Clementino Fraga Filho, Universidade Federal do Rio de Janeiro

Av. Brigadeiro Trompowski s/n Secretaria de Endocrinologia Cidade Universitária, Ilha do Fundão 21941-950 - Rio de Janeiro, RJ, Brazi leilianegc@globo.com

Received on Feb/15/2013 Accepted on Apr/6/2013

\begin{abstract}
Autoimmune thyroid diseases (AITD) are the main causes of thyroid dysfunction and the most common autoimmune diseases in the world. An association between AITD and infections with the human immunodeficiency virus (HIV), in combination with the effects of highly active antiretroviral therapy (HAART), has been suggested by several research groups. The aim of the present study was to evaluate the frequency of thyroid dysfunction and AITD in women > 35 years of age infected with HIV, and to identify factors associated with the emergence of these thyroid abnormalities. HIV-infected women $(n=153)$ selected from the infectious disease outpatient clinic at a University Hospital in Rio de Janeiro were characterized based on their circulating $\mathrm{CD}^{+}$lymphocytes levels, viral loads, serum TSH levels, and the presence of FT4 and anti-thyroperoxidase antibodies (TPO-Ab). A total of 129 participants were on HAART and 24 were not. The frequency of thyroid disorders was $7.8 \%$ (12/153 patients) and all were on HAART at the time of diagnosis, yielding a prevalence of $9.3 \%$ in patients receiving HAART compared with $0 \%$ in patients not on HAART. AITD, hyper, and hypothyroidism were detected in $4.6 \%, 3.1 \%$, and $4.1 \%$ of HAART patients. It was not detected any thyroid dysfunction or autoimmunity in HIVinfected women not on HAART.This study demonstrated an association between HAART and the development of AITD. In addition AITD only developed in HAART patients also presenting with undetectable viral loads and slightly elevated CD4+T cell counts. Arq Bras Endocrinol Metab. 2013;57(6):450-6
\end{abstract}

Keywords

Autoimmune thyroid disease; thyroid dysfunction; hypothyroidism; hyperthyroidism; HIV; anti-retroviral therapy; immunity

\section{RESUMO}

Doenças tiroidianas autoimunes (DTAl) são a maior causa de disfunção tiroidiana e são as doenças autoimunes mais comuns no mundo. A associação entre DTAl e infecções com o vírus da imunodeficiência humana (HIV), em combinação com a terapia antirretroviral altamente ativa (HAART), foi sugerida por vários grupos de pesquisadores. 0 objetivo do presente estudo foi avaliar a frequência de disfunção tiroidiana e DTAl em mulheres com mais 35 anos de idade infectadas com o HIV e identificar fatores associados com a emergência dessas anormalidades tiroidianas. As mulheres infectadas com HIV ( $n=153)$, selecionadas do ambulatório de doenças infecciosas de um hospital universitário do Rio de Janeiro, foram caracterizadas com base no nível de linfócitos $\mathrm{CD}^{+}$circulantes, carga viral, níveis deTSH sérico e presença de anticorpos $\mathrm{FT} 4$ e antitiroperoxidase (TPO-Ab). Um total de 129 participantes se tratava com HAART e 24 não. A frequência de desordens da tiroide foi 7,8\% (12/153 pacientes) e todas estavam em tratamento com HAART no momento do diagnóstico, levando a uma prevalência 9,3\% em pacientes recebendo HAART, em comparação com $0 \%$ em pacientes não tratadas com HAART. DTAI, hipertireoidismo e hipotireoidismo foram detectados em $4,6 \%, 3,1 \%$ e 4,1\% das pacientes tratadas com HAART. Não foram detectadas disfunção tiroidiana ou autoimunidade em mulheres infectadas com HIV e não tratadas com HAART. Este estudo demonstrou uma associação entre a HAART e o desenvolvimento de DTAl. Além disso, a DTAl apenas se desenvolveu em pacientes tratadas com HAART e que apresentavam cargas virais indetectáveis e contagens de células CD4+T levemente elevadas. Arq Bras Endocrinol Metab. 2013;57(6):450-6

\section{Descritores}

Doença tiroidiana autoimune; disfunção tiroidiana; hipotiroidismo; hipertiroidismo; HIV; terapia antirretroviral; imunidade 


\section{INTRODUCTION}

A utoimmune thyroid diseases (AITD) are the most prevalent autoimmune diseases worldwide. In addition, they are the main causes of thyroid dysfunction, including hypo- and hyperthyroidism. The spectrum of thyroid autoimmune diseases includes Hashimoto thyroiditis, Graves' disease and post-partum thyroidits (1-4).

The association between thyroid dysfunction and HIV infection, in combination with the impact of highly active anti-retroviral therapy (HAART) has been demonstrated in several studies (5-8). However, these studies did not demonstrate that AITD was associated with thyroid dysfunction (7). For these reasons, non-thyroid sick syndrome and potential pituitary dysfunction should be included as part of the differential diagnosis in these patients. The possibility that different conditions, unrelated to primary thyroid disease, are cause of laboratorial abnormalities in thyroid hormone dosages was corroborated by other studies that did not find associations between thyroid diseases and HIV infection (9-11). Despite some evidence of this association, the precise mechanisms involved in the development of these diseases in HIV-infected subjects remains undefined (12-16).

A population survey conducted in the city of Rio de Janeiro showed that $10 \%$ of women $>35$ years of age had detectable circulating anti-thyroperoxidase antibodies (TPO-Ab) (17) and a prevalence of hypo- and hyperthyroidism (including overt and subclinical diagnosis) in 12 and 3.5\%, respectively (17). This findings are in accordance with other cross-sectional studies that evaluated different populations in other countries and found similar frequencies (17-23).

The aim of the present study was to evaluate the frequency of thyroid dysfunction and thyroid autoimmunity in HIV-infected women $>35$ years of age, who were recruited from the outpatient clinic at the University Hospital in Rio de Janeiro, Brazil. In addition, we evaluated determinants potentially associated with the emergence of these thyroid abnormalities in the studied population (demographic characteristics, levels of $\mathrm{CD}^{+} \mathrm{T}$ lymphocytes, viral load, duration of HIV infection, and HAART use).

\section{MATERIALS AND METHODS}

\section{Study population}

HIV-1 infected women were recruited from a cohort of subjects treated at the Clementino Fraga Filho Univer- sity Hospital (HUCFF) at the Federal University of Rio de Janeiro (UFRJ). The HUCFF is a large teaching hospital located in Rio de Janeiro, Brazil. This study was approved by the Ethics Committee of the HUCFF School of Medicine at the UFRJ. Informed consent was obtained from each patient before the study was initiated.

HIV-1 infected women were enrolled from a cohort of HIV-l infected subjects treated at the HUCFF. Women were $>35$ years of age and attended regular outpatient visits. All participants had updated telephone numbers, current $\mathrm{CD}^{+} \mathrm{T}$ cell counts, and viral load information. Patients that used drugs that potentially interfered with thyroid function (e.g., Amiodarone or costicosteroids) or who were recently hospitalized were excluded. Patients were invited to participate by telephone and enrollment was performed between August 2008 and January 2009. After informed consent was obtained a detailed interview and blood collection for laboratory analysis was performed. The interview was used to capture demographic information, family history of thyroid diseases, time of HIV infection diagnosis, and use of HAART.

\section{Laboratory methods}

Serum TSH (reference range: 0.4-4.0 $\mu \mathrm{UI} / \mathrm{L}$, FT4 (reference range: $0.8-1.9 \mathrm{ng} / \mathrm{dL}$ ), and TPO-Ab levels (normal $<35 \mu \mathrm{UI} / \mathrm{mL}$ ) were determined using immunochemiluminescence (ECLIA, Modular, Roche, German) at the Sergio Franco Medicina Diagnóstica, Rio de Janeiro. Patients with low TSH levels $(<0.4$ $\mu \mathrm{UI} / \mathrm{mL}$ ) also had anti-TSH receptor (TRAB) antibody levels measured (RIE, RSR, UK). The most current HIV-1 viral load (b-DNA, Siemens, USA) and CD4 ${ }^{+}$ lymphocyte count information was obtained from the patient's charts. For patients with established history of thyroid disease, HIV-1 viral load and CD4 $4^{+}$lymphocyte count at the time of thyroid disease diagnosis were obtained from the patient's charts.

Hypothyroidism was defined by elevated TSH serum levels combined with low FT4 levels. Hyperthyroidism was defined by low serum TSH levels and high serum FT4 levels. Patients were diagnosed with subclinical hypo- or hyperthyroidism only when serum TSH levels were abnormal. AITD was defined by the presence of circulating anti-thyroid antibodies (including TPO-Ab and/or TRAB in serum). 
There was one patient who had isolated hypothyroxinemia, defined by the presence of low serum FT4 levels with serum TSH levels in the normal range.

\section{Data analysis}

The SPSS program (version 13.0 for Windows) was used for data entry and statistical analysis. A descriptive analysis and comparisons of categorical variables between the two groups were performed using the Chi-square or Fisher's test when appropriate. Student's $t$ test or Mann-Whitney tests were performed to compare continuous variables. $\mathrm{P}$ values $<0.05$ were considered significant. Pearson's coefficient was determined after logarithmic transformation to establish correlations between two variables.

\section{RESULTS}

Female participants $(\mathrm{n}=153)$ with a mean age of 46.5 \pm 9.1 years (range 35-88) participated in the study. The mean interval time from HIV diagnosis to study inclusion was 11 years (ranging from 4 months to 20 years). One hundred twenty nine women $(84 \%)$ were on HAART from 1 month to 19 years (mean number of years on HAART was 8 ).

Twelve $(7.8 \%)$ of all participants of the study $(12 / 153)$, presented some form of thyroid disorder (thyroid dysfunction or autoimmunity). Specifically, 6 patients were diagnosed with a thyroid disorder at the time the study began, and 6 patients had an established history of thyroid disease. Thyroid disorders in these 12 women were diagnosed following the diagnosis of HIV infection and all 12 were on HAART at the time the thyroid disease diagnosis was determined (including 6 patients with previous history of thyroid disease). Among these 6 patients, 2 were on levothyroxine to treat overt hypothyroidism, and 2 were using anti-thyroid drugs for the treatment of Graves' disease at the time the study began.

As shown in Table 1, six patients had AITD (defined by the presence of circulating TPO-Ab and/or TRAB) in the whole group studied $(6 / 153)$, corresponding to $3.9 \%$ of the total. Evaluation of patients presenting primary hypothyroidism $(n=6)$ identified 2 patients with circulating anti-thyroid antibodies (one of them with overt hypothyroidism). Another patient with overt hypothyroidism but not detectable circulating anti-thyroid antibodies. Four patients had subclinical hypothyroidism (only one had positive circulating TPO-Ab). One patient had low serum FT4 levels with serum TSH levels in the normal range, and no detectable circulating TPO-Abs. This last patient, with isolated hypothyroxinemia, had low CD4+ levels (103 cells/ $\mu \mathrm{L})$ and a high viral load (> 10,000 copies).

One patient presented with Hashimoto's thyroiditis but no thyroid dysfunction, and 4 patients had hyperthyroidism. Among patients presenting with hyperthyroidism $(\mathrm{n}=4)$, only one did not have circulating

Table 1. Frequencies of thyroid disorders in women treated or untreated with HAART

\begin{tabular}{|c|c|c|c|c|}
\hline & $\begin{array}{l}\text { All patients } \\
(n=153)\end{array}$ & $\begin{array}{l}\text { Patients on HAART } \\
\quad(n=129)\end{array}$ & $\begin{array}{l}\text { Patients not on HAART } \\
\qquad(\mathrm{n}=24)\end{array}$ & $P$ values \\
\hline Thyroid disorders & $12(7.8 \%)$ & $12(9.3 \%)$ & 0 & 0.119 \\
\hline Isolated hypothyroxinemia & $1(0.6 \%)$ & $1(0.8 \%)$ & 0 & 0.900 \\
\hline Hypothyroidism & $6(3.9 \%)$ & $6(4.6 \%)$ & 0 & 0.348 \\
\hline Overt hypothyroidism & $2: 153(1.3 \%)$ & $2(1.5 \%)$ & 0 & 0.787 \\
\hline SCH with AITD & $1: 153(0.6 \%)$ & $1(0.8 \%)$ & 0 & 0.938 \\
\hline SCH without AITD & $3: 153$ (1.9\%) & $3(2.3)$ & 0 & 0.600 \\
\hline Hyperthyroidism & $4(2.6 \%)$ & $4(3.1 \%)$ & 0 & 0.402 \\
\hline Overt hyperthyroidism & $2: 153(1.3 \%)$ & $2(1.5 \%)$ & 0 & 0.787 \\
\hline SChyper with AITD & $1: 153(0.6 \%)$ & $1(0.8 \%)$ & 0 & 0.880 \\
\hline SChyper without AITD & $1: 153(0.6 \%)$ & $1(0.8 \%)$ & 0 & 0.850 \\
\hline TPO-Ab* & $5(3.2 \%)$ & $5(3.8 \%)$ & 0 & 0.421 \\
\hline $\mathrm{TRAB}^{+\star *}$ & $3(1.9 \%)$ & $3(2.3 \%)$ & 0 & 0.597 \\
\hline AlTD ${ }^{\star * *}$ & $6(3.9 \%)$ & $6(4.6 \%)$ & 0 & 0.353 \\
\hline
\end{tabular}

Patients not treated with HAART who presented thyroid disorders. P values $>0.10$ between patients with or without HAART (Fisher's exact test). ${ }^{*}$ Positive anti-thyroperoxidase serum antibodies (TPO-Ab). ${ }^{\star \star}$ Positive serum anti-TSH-receptor antibodies (TRAB). ${ }^{\star \star \star}$ Autoimmune thyroid diseases (including the presence of TPO-Ab and/or TRAB). 
TRAB, and this patient had subclinical hyperthyroidism without circulating anti-thyroid antibodies.

Evaluation of the HAART treatment subgroup (129 patients) only identified 12 patients with thyroid disorders (12/129) and 6 patients with AITD (6/129), corresponding to $9.3 \%$ and $4.6 \%$, respectively, in this subgroup. Hypo- and hyperthyroidism were detected in $4.6 \%$ (6/129 patients) and 3.1\% (4/129 patients) of the women in this subgroup (Table 1 ).

\section{STUDY OF HIV-INFECTED WOMEN WITH THYROID DISORDERS}

Table 2 compares selected variables between women in the study, based on the presence or absence of thyroid disorders. Mean age was not different between patients with or without thyroid abnormalities, nor was the time of HIV diagnosis or the mean time they were on
HAART. Only one of the AITD patients had a family history of thyroid disease.

All women with hyperthyroidism and AITD (independent of thyroid function) had undetectable viral loads (Table 2). The median $\log _{10}$ viral load in women without hyperthyroidism and without AITD was 1.59.

Independent of HAART use, $\mathrm{CD}^{+}{ }^{+}$cells counts tended to be higher in patients with hyperthyroidism or AITD (Table 2). However, these associations were not statistically significant. As expected, the absolute number of CD4+ T cells correlated negatively with viral copies $(\mathrm{r}=-0.422 ; \mathrm{p}<0.001)$.

\section{DISCUSSION}

The present study did not demonstrate a higher frequency of thyroid dysfunction or AITD in HIV-infected women than had previously been reported in the literature re-

Table 2. Comparisons between HIV-infected patients on HAART, with or without diagnosis of thyroid abnormalities

\begin{tabular}{|c|c|c|c|}
\hline \multicolumn{4}{|c|}{ Only patients on HAART* } \\
\hline Any kind of thyroid disorder ${ }^{\star \star}$ & Yes $(n=12)$ & No $(n=117)$ & $P$ value \\
\hline Mean age (years) & $44.8 \pm 8.7$ & $47.1 \pm 9.5$ & 0.385 \\
\hline Mean number of years diagnosed with HIV & $11.5 \pm 5.5$ & $10.8 \pm 5.0$ & 0.590 \\
\hline Mean CD4+ cells (cells/uL) & $695 \pm 368$ & $589 \pm 312$ & 0.303 \\
\hline Mean number of years of HAART use & $7.7 \pm 3.9$ & $7.7 \pm 4.8$ & 0.783 \\
\hline Undetectable viral load (\%) & $91.7 \%(n=11)$ & $78.6 \%(n=92)$ & 0.257 \\
\hline 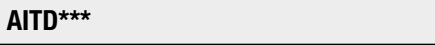 & Yes $(n=6)$ & No $(n=123)$ & $P$ values \\
\hline Mean age (years) & $47.8 \pm 11.2$ & $46.8 \pm 9.4$ & 0.813 \\
\hline Mean number of years post-HIV infection & $10.8 \pm 5.0$ & $10.8 \pm 4.1$ & 0.995 \\
\hline Mean CD4+ cells (cells/ $/ \mathrm{L})$ & $825 \pm 357$ & $588 \pm 313$ & 0.096 \\
\hline Mean number of years of HAART use & $7.3 \pm 4.5$ & $7.7 \pm 4.8$ & 0.980 \\
\hline Undetectable viral load (\%) & $100 \%(N=6)$ & $78.9 \%(\mathrm{~N}=97)$ & 0.251 \\
\hline Hypothyroidism & Yes $(n=6)$ & No $(n=123)$ & $P$ values \\
\hline Mean age (years) & $48.6 \pm 9.5$ & $46.8 \pm 9.5$ & 0.602 \\
\hline 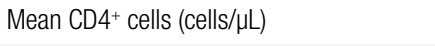 & $600 \pm 407$ & $599 \pm 315$ & 0.996 \\
\hline Mean number of years diagnosed with HIV & $14.0 \pm 3.8$ & $10.6 \pm 5.0$ & 0.109 \\
\hline Mean number of years of HAART use & $10.3 \pm 4.7$ & $7.5 \pm 4.7$ & 0.157 \\
\hline Undetectable viral load (\%) & $66,7 \%(n=4)$ & $80,5 \%(n=99)$ & 0.348 \\
\hline Hyperthyroidism & Yes $(n=4)$ & No $(n=125)$ & $P$ values \\
\hline Mean age (years) & $49.0 \pm 12.2$ & $46.8 \pm 9.4$ & 0.671 \\
\hline Mean $\mathrm{CD} 4^{+}$cells (cells/HL) & $746 \pm 379$ & $594 \pm 316$ & 0.097 \\
\hline Mean number of years diagnosed with HIV & $11.5 \pm 5.5$ & $10.8 \pm 5.0$ & 0.808 \\
\hline Mean number of years of HAART use & $7.0 \pm 2.1$ & $7.7 \pm 4.8$ & 0.909 \\
\hline Undetectable viral load (\%) & $100 \%(n=4)$ & $79.2 \%(n=99)$ & 0.402 \\
\hline
\end{tabular}

* Highly active anti-retroviral therapy; ${ }^{*}$ Thyroid disorders include: thyroid dysfunction (serum TSH out of the normal range) or thyroid autoimmunity (positive serum antibodies against TSH receptor [TRAB] or thyreoperoxidasis [TPO-Ab]). ${ }^{\star \star \star}$ Autoimmune thyroid disease. 
garding the general population (17-23). Furthermore, it was shown that some patients $(4 / 153)$ had subclinical thyroid dysfunction without circulating anti-thyroid antibodies, which may not have clinical impact (19-23).

Also, the results demonstrated a frequency of thyroid abnormalities lower than previously reported by Schieri and cols., who analyzed Rio de Janeiro women of the same age as those described in this study. This study reported a 10 and $12.3 \%$ prevalence of Hashimoto's thyroiditis and hypothyroidism, respectively (17). The inclusion of women of the same age and from the same city enabled the comparison between studies with less confounding bias. However, a limitation of this comparison can be attributed to other inclusion criteria, since Schieri and cols. conducted a population survey on women who were not in an ambulatory setting (i.e., from a tertiary hospital).

A comparative analysis was performed between patients treated with and without HAART, which demonstrated that all HIV-infected women were on HAART at the time of thyroid disease diagnosis. Despite these findings, the relationship between HAART and the manifestation of thyroid dysfunction and autoimmunity could not be proved. During the course of this study, we were also unable to identify associations with the duration of HAART therapy or HIV infection, and the development of different thyroid abnormalities.

Previous studies conducted by Madeddu and cols. demonstrated a positive association between HAART and thyroid diseases. They evaluated 182 patients treated with HAART and 20 who were not. This study demonstrated that thyroid dysfunction was diagnosed in $12.6 \%$ of HAART patients, but not in any patients in the untreated control group. However, the most prevalent dysfunction reported was subclinical hypothyroidism in the absence of detectable serum TPO-Abs in patients with this thyroid dysfunction (5). Because of this, other diseases associated with elevated serum TSH levels should be included as part of the differential diagnosis (5).

Jain and cols. also suggested that serum TSH levels may be positively associated with the progression of HIV infection, but no association between AITD and HIV infection was demonstrated based on the evaluation of 50 patients (24).

Contributing to the data suggesting that there is no association between primary thyroid dysfunction and HAART is a cross-sectional, multicenter study of $\mathbf{3 5 0}$ HIV-infected patients presenting elevated hypothy- roidism rates in males $(16 \%)$ associated with low $\mathrm{CD}^{+}$ counts (7). Based on these data, it was demonstrated that serum TSH levels did not correlate with autoimmune disease and further suggested that non-thyroid diseases and pituitary disorders should be included as part of the differential diagnosis of these patients (7). In addition, a case control study carried out by Afhami and cols. was unable to demonstrate associations between hypothyroidism and HAART, mean CD4+ T cell counts, or the duration of HIV infection (10). In this latter study, 85 subjects were evaluated including 15 hypothyroid cases and 70 euthyroid HIV-infected patients that served as controls (10). Despite these related studies that demonstrated negative associations between HAART therapy and thyroid diseases, other studies have found correlations between thyroid disease and HIV infection $(8,9)$.

Discrepancies regarding the effects of HAART on thyroid function are found in both small and large-scale studies $(8,9)$. One of these studies was a prospective study examining HIV-positive individuals at the Royal Free Hospital that demonstrated a higher incidence of thyroid dysfunction in this population. Furthermore, based on these findings, they did not recommend routine thyroid testing for these patients. This cohort included 3,584 HIV-positive individuals tested for thyroid function at least once (from these 900, were on HAART) (9). The findings from the study carried out using the Chelsea and Westminster Hospital HIV cohort were published soon after that (8). In this study, 2,437 HIV-infected patients were evaluated over an 11-year period (1995-2006). The incidence of hyperthyroidism was 3.4 per 10,000 treated patient-years and the incidence of hypothyroidism was 10.7 (95\% confidence interval: 6.9 to 15.8 ) per 10,000 treated patient-years. In this retrospective cohort, there was a higher-than-expected incidence of hypothyroidism (8).

Previous studies have suggested that hyperthyroidism (specifically Graves' disease) and not hypothyroidism is associated with HIV infection and HAART (6$8)$. Furthermore, it was recently suggested that Graves' disease development represents an immune reconstitution inflammatory syndrome (IRIS) induced by HAART (25). Evaluation of the studies cited above suggested that the association between thyroid dysfunction progression, or development of autoimmunity, in HAART patients remains controversial.

The proposed mechanisms associated with the potential development of thyroid diseases and HAART 
vary significantly. However, induction of immune restoration by HAART has been studied by several investigators as a potential mechanism (13-15,28-19). In addition, the potential homology between HIV and thyroid proteins has been suggested especially with regard to TSH receptor proteins (12).

The immunopathogenesis resulting in Graves' disease following recovery from severe $\mathrm{T}$ cell depletion that occurs not only following immune reconstitution of HIV patients but also following alemtuzumab treatment (monoclonal anti-CD52 that depletes $\mathrm{T}$ and $\mathrm{B}$ cells) remains undefined. However, an acquired defect associated with tolerance induction may predispose some individuals to higher rates of autoimmune disease (12,16,28-32).

Central $\mathrm{T}$ cell tolerance may be lost as a result of thymic dysfunction in some HIV-infected patients and peripheral $\mathrm{T}$ cell tolerance may be impaired as a consequence of reduced CTLA-4 function, a molecule important in promoting $\mathrm{T}$ cell tolerance to thyroid auto-antigens (33). Breaking self-tolerance and loss of immune regulation associated with HIV infection may be also associated with abnormalities in FOXP3 expression in $\mathrm{CD}^{+}$and $\mathrm{CD}^{+}$cells (34). Lim and cols. showed that untreated HIV-infected patients had lower numbers of total FoxP3 ${ }^{+}$cells and $\mathrm{FoxP}^{+} \mathrm{CD}^{+} \mathrm{T}$ cells when the $\mathrm{CD}^{+} \mathrm{T}$ cells were $<300$ cells $/ \mu \mathrm{L}$ compared with HIV-infected patients with higher than $400 \mathrm{CD}^{+}$ $\mathrm{T}$ cells $/ \mu \mathrm{L}$ (34). Furthermore, these FoxP3 ${ }^{+} \mathrm{CD}^{+} \mathrm{T}$ cells expressed less CTL4 then Fox $\mathrm{P}^{+} \mathrm{CD} 4{ }^{+}$cells (34).

The present study compared CD4 ${ }^{+} \mathrm{T}$ cell levels and viral loads in women with or without thyroid disorders, and demonstrated that $\mathrm{CD} 4^{+}$levels tended to be higher and viral loads lower in patients with hyperthyroidism and AITD, suggesting that these patients had an effective immune responses at the time of thyroid disease diagnosis. Also, this study demonstrated that all patients diagnosed with hyperthyroidism and AITD had undetectable viral loads. These findings further suggest that differential diagnoses should be carried out during the evaluation of severely immunosuppressed HIV-infected patients presenting with low serum TSH levels.

The limitation of this comparative study was the inclusion of women from a tertiary hospital where the majority of patients were on HAART. Furthermore, patients not receiving HAART in this study probably had elevated $\mathrm{CD}^{+}$cells levels and low viral loads, and therefore, a functioning immune system.

\section{CONCLUSION}

The present study demonstrated a lack of correlation between thyroid dysfunction and/or autoimmunity in HIV-infected women treated or untreated with HAART. An association between HAART and the development of autoimmune thyroid diseases was suggested since AITD only developed in patients on HAART who had undetectable viral loads and slightly higher levels of $\mathrm{CD}^{+}{ }^{+} \mathrm{T}$ cells. However, additional studies will be needed to confirm this association.

Acknowledgements: we would like to thank Roche Diagnóstica Brasil Ltda. and Sergio Franco Medicina Diagnóstica who provided some of the laboratory analyses described. We would also like thank Fundação de Amparo à Pesquisa (Faperj).

Disclosure: no potential conflict of interest relevant to this article was reported.

\section{REFERENCES}

1. Philippe J. Graves' disease in 2009. Rev Med Suisse. 2009;5:764-8.

2. Brown RS. Autoimmune thyroid disease: unlocking a complex puzzle. Curr Opin Pediatr. 2009;21:523-8.

3. Nakamura H, UsaT, Motomura M, IchikawaT, Nakao K, Kawasaki E, et al. Prevalence of interrelated autoantibodies in thyroid diseases and autoimmune disorders. J Endocrinol Invest. 2008;31:861-5.

4. Weetman AP. Graves' disease. N Engl J Med. 2000;343:1236-48.

5. Madeddu G, Spanu A, Chessa F, Calia GM, Lovigu C, Solinas P, et al. Thyroid function in human immunodeficiency virus patients treated with highly active antiretroviral therapy (HAART): a longitudinal study. Clin Endocrinol (Oxf). 2006;64:375-83.

6. Jubalt V, Penfornis A, Schillo F, Hoen B, Izembart M, Timsit J, et al. Sequential occurrence of thyroid autoantibodies and Graves' disease after immune restoration in severely immunocompromised human immunodeficiency virus-1-infected patients. J Clin Endocrinol Metab. 2000;85:4254-7.

7. Beltran S, Lescure FX, Desailloud R, Douadi Y, Smail A, Esper IE, et al. Increase prevalence of hypothyroidism among human immunodeficiency virus infected patients: a need for screening. Clin Infect Dis. 2003;37:579-83.

8. Nelson M, Powles T, Zeitlin A, Sen P, Scourfield A, Bower M, et al. Thyroid dysfunction and relationship to antiretroviral therapy in HIV-positive individuals in the HAART era. J Acquir Immune Defic Syndr. 2009;50:113-4.

9. Madge S, Smith CJ, Lampe FC, Thomas M, Johnson MA, Youle M, et al. No association between HIV disease and its treatment and thyroid function. HIV Medicine. 2007;8:22-7.

10. Afhami S, Haghpanah V, Heshmant R, Rasoulinejad M, Izadi M, Lashkari $A$, et al. Assessment of the factors involving in the development of hypothyroidism in HIV-infected patients: a case-control study. Infection. 2007;35:334-8.

11. Hoffmann JC, Brown TT. Thyroid function abnormalities in HIV-infected patients. Clin Infec Diseases. 2007;45:488-94.

12. Desailloud R, Hober D. Viruses and thyroiditis: an update. Virol J. 2009;6:5.

13. Crum NF, Ganesan A, Johns ST, Wallace MR. Graves' disease: an increasingly recognized immune reconstitution syndrome. AIDS. 2006;20:466-9.

14. Chen F, Day SL, Metcalfe RA, Sethi G, Kapembwa MS, Brook MG, et al. Characteristics of autoimmune thyroid disease occurring as 
a late complication of immune reconstitution in patients with advanced human immunodeficiency virus (HIV) disease. Medicine (Baltimore). 2005;84:98-106.

15. Knysz B, Bolanowski M, Klimczak M, Gladysz A, Zwolinska K. Graves' disease as an immune reconstitution syndrome in an HIV-1-positive patient commencing effective antiretroviral therapy: case report and literature review. Viral Immunol. 2006;19:102-7.

16. Zandman-Goddard G, Shoenfeld Y. HIV and autoimmunity. Autoimmun Rev. 2002;1:329-37.

17. Sichieri R, Baima J, MaranteT, Vasconcellos MTL, Moura AS, Vaismam M. Low prevalence of hypothyroidism among black and Mulatto people in a population-based study of Brazilian women. Clin Endocrinol. 2007;66:803-7.

18. Hoogendoom EH, Hermus AR, de Vegt F, Ross HA, Verbek AL, Kiemeney $L A$, et al. Thyroid function and prevalence of anti-thyroperoxidase antibodies in a population with borderline sufficient iodine intake: influences of age and sex. Clin Chem. 2006;52:104-11.

19. Hollowell JG, Staehling NW, Flanders WD, Hannon WH, Gunter EW, Spencer CA, et al. Serum TSH, T4 and thyroid antibodies in the United States population (1988-1994): National Health and Nutrition. J Clin Endocrinol Metab. 2002;87:489-99.

20. Knudsen N, Jorgensen T, Rasmussen S, Christiansen E, Perrild H. The prevalence of thyroid dysfunction in a population with borderline iodine deficiency. Clin Endocrinol. 1999;52:361-7.

21. O'Leary PC, Fedderma PH, Michelangeli VP, Leedman PJ, Chew GT, Knuiman $M$, et al. Investigations of thyroid hormones and antibodies based on a community health survey: The Busselton thyroid study. Clin Endocrinol. 2006;64:97-104.

22. BjoroT, Holmen J, Kruger O, Midthjell K, Hunstad K, SchreinerT, et al. Prevalence of thyroid disease, thyroid dysfunction and thyroid peroxidase antibodies in a large, unselected population. The health Study of Nord-Trondelag (HUNT). Eur J Endocrinol. 2000;143:639-47.

23. Canaris GJ, Manowitz NR, Mayor G, Ridgway EC. The Colorado thyroid disease prevalence study. Arch Intern Med. 2000;160:526-34.

24. Jain G, Devpura G, Gupta BS. Abnormalities in the thyroid function tests as surrogate marker of advancing HIV infection in infected adults. J Assoc Physicians India. 57:508-10.
25. Rasul S, Delapenha R, Farhat F, Gajjala J, Zahra SM. Graves' disease as a manifestation of immune reconstitution in HIV-1-infected individuals after initiation of highly active antiretroviral therapy. AIDS Res Treat. 2011:743597.

26. Singer PA, Cooper DS, Levy EG, Ladenson PW, Braverman LE, Daniels G, et al. Treatment guidelines for patients with hyperthyroidism and hypothyroidism. Standards of Care Committee, American Thyroid Association. JAMA. 1995;273:808:812.

27. Stagnaro-Green A, Abalovich M, Alexander E, Azizi E, Mestman $\mathrm{J}$, Negro R, et al. Guidelines of the American Thyroid Association for the Diagnosis and Management of Thyroid Disease. Thyroid. $2011 ; 21: 1-45$.

28. French MA, King MS, Tschampa JM, Silva BA, Landay AL. Serum immune activation markers are persistently increased in patients with HIV infection after 6 years of antiretroviral therapy despite suppression of viral replication and reconstitution of CD4+T cells. J Infect Dis. 2009;200:1212-5.

29. Price $P$, Mathiot N, Krueger R, Stone S, Keane NM, French MA. Immune dysfunction and immune restoration disease in HIV patients given highly active antiretroviral therapy. J Clin Virol. 2001;22:279-87.

30. French MA. Immune reconstitution inflammatory syndrome: a reappraisal. Clin Infec Dis. 2009;48:101-7.

31. Polkowska $E$, Bossowski $A$. The role of lymphocytes and secrete cytokines in autoimmune thyroid diseases. Pediatr Endocrinol Diabetes Metab. 2009;15:114-7.

32. Caporossi AP, Bruno G, Salemi S, Mastroianni C, Falciano M, Salotti A. Autoimmune T-cell response to the CD4 molecule in HIV-infected patients. Viral Immunol. 1998;11:9-17.

33. French MA, Lewin SR, Dykstra C, Krueger R, Price P, Leedman PJ. Graves' disease during immune reconstitution after highly active antiretroviral therapy for HIV-infection: evidence of thymic dysfunction. AIDS Res Hum Retroviruses. 2004;20:157-62.

34. Lim A, French MA, Price P. CD4+ and CD8+ cells expressing FoxP3 in HIV-infected patients are phenotypically distinct and influenced by disease severity and antiretroviral therapy. J Acquir Immune Defic Syndr. 2009;51:248-57. 